\title{
An atypical presentation of ANCA- associated retinal vasculitis in a young Malay woman
}

Jin Yi Yap ${ }^{1}$, Mohtar Ibrahim², Embong Zunaina ${ }^{3}$

${ }^{1}$ Department of Ophthalmology, School of Medical Sciences Health Campus, Universiti Sains Malaysia, Kubang Kerian, Kelantan, Malaysia; ${ }^{2}$ Hospital Universiti Sains Malaysia, Health Campus Universiti Sains Malaysia, Kubang Kerian, Kelantan, Malaysia; ${ }^{3}$ Department of Surgery, School of Medical Sciences, Universiti Malaysia Sabah, Kota Kinabalu, Sabah, Malaysia

\section{Abstract}

We describe a case of antineutrophil cytoplasmic antibody (ANCA)-associated retinal vasculitis in a 21-year-old previously healthy Malay woman, who presented to us with complaints of sudden painless loss of vision in her left eye. Her vision upon presentation was counting fingers and her fundus examination showed retinal vasculitis and ischemic changes. Fundus fluorescein angiography showed leakage from the vasculitic retinal vessels, resulting in macular oedema. All investigations were normal, except that a full blood test showed eosinophilia and an autoimmune screening revealed positive perinuclear staining-ANCA, which led us to diagnose ANCA-associated retinal vasculitis. The patient was comanaged with the rheumatology team. She was started on a high-dose intravenous steroid followed by a tapering dose of an oral steroid. Improvement was noted from the resolution of macular oedema evident on optical coherence tomography of the macula. However, vision remained poor and unchanged.

Keywords: autoimmune diseases, antineutrophil cytoplasmic antibody (ANCA), retinal vasculitis

Correspondence: Jin Yi Yap, Trainee MA Ophthalmology, Department of Ophthalmology, School of Medical Sciences Health Campus, Universiti Sains Malaysia, 16150 Kubang Kerian, Kelantan, Malaysia.

E-mail:yjy16my@yahoo.com 


\section{Gejala vaskulitik retina berkait ANCA yang tidak tipikal dalam pesakit wanita muda berbangsa Melayu}

\section{Abstrak}

Kami menghuraikan satu kes antibodi antineutrofil sitoplasmik (ANCA) yang berkaitan dengan vaskulitik retina pada wanita Melayu yang berusia 21 tahun yang mengadu kehilangan penglihatan tanpa sakit di mata kirinya. Penglihatan beliau semasa mula mendapat gejala ialah kiraan jari (Counting Finger)dan pemeriksaan fundusnya menunjukkan vaskulitik retina dan perubahan iskemia. Angiografi fluoresen fundus menunjukkan kebocoran dari keradangan salur darah retina, menyebabkan bengkak pada makular. Semua penyiasatan adalah normal, kecuali ujian darah menunjukkan eosinofilia dan pemeriksaan autoimun mendedahkan positif perinuklear positif-ANCA, yang menyokong diagnosis vasculitik retina yang berkaitan dengan ANCA. Pesakit turut dirawat bersama dengan pasukan reumatologi. Rawatan bermula dengan steroid intravena dos yang tinggi diikuti dengan dos pengurangan berkala ubat steroid oral. Proses penyembuhan dapat diperhatikan dari pengurangan bengkakan pada makula yang jelas pada tomografi koheren optik makula (OCT macular). Walaubagaimanapun, penglihatan kekal teruk, tidak berubah.

Kata kunci: antibodi antineutrofil sitoplasmik (ANCA), penyakit autoimun, vasculitik retina

\section{Introduction}

Antineutrophil cytoplasmic antibody (ANCA) is a serological marker for the diagnosis of a group of small vessel pauci-immune vasculitis, also known as ANCA-associated vasculitis (AAV). ${ }^{1}$ It is a rare cause of autoimmune retinal vasculitis, mainly affecting Caucasians in the older age group. This case report highlights a rare case of AAV which includes Asian ethnicity, young age, and presentation of retinal vasculitis without systemic involvement.

\section{Methods}

Case report. 


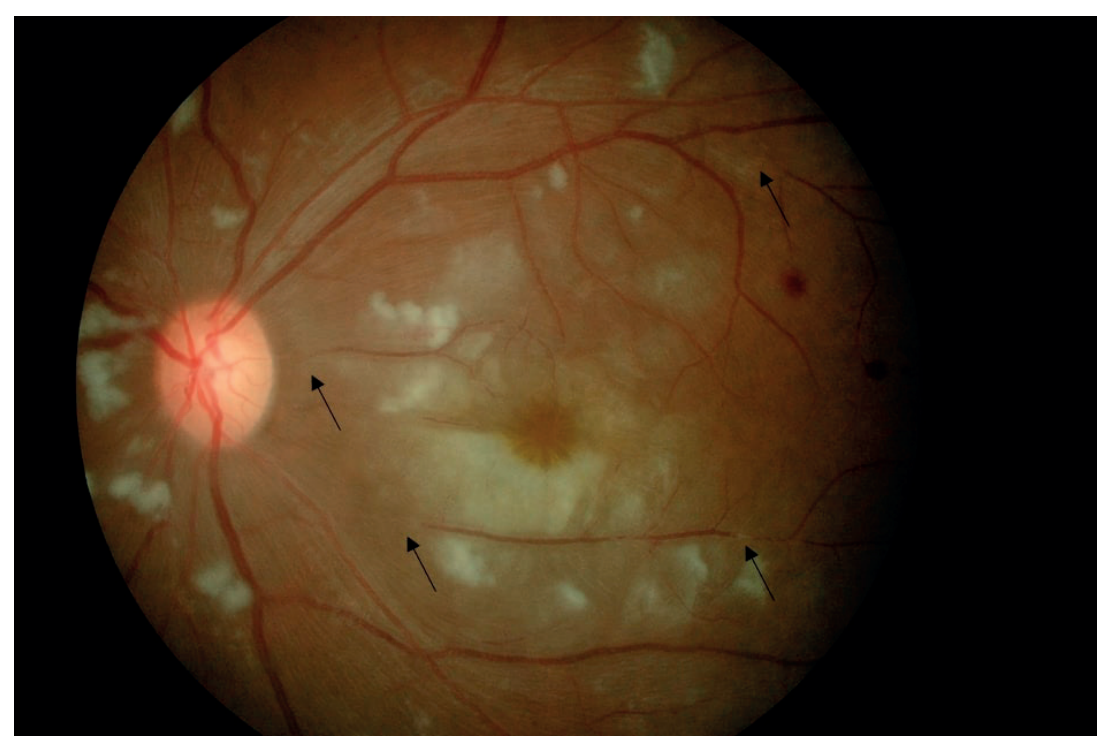

Fig. 1. Left fundus showed multiple cotton wool spots at the macular area and surrounding the nasal portion of the optic disc, with occlusion of both the superior and inferior arcade of the retinal arterioles (black arrows), as well as multiple retinal haemorrhages in the superotemporal retina.

\section{Results}

A 21-year-old healthy Malay woman presented with sudden onset of painless central scotoma on the left eye for one week. On presentation, her visual acuity was counting fingers in the left eye and 20/20 in the right eye. Anterior segment examination of the left eye was unremarkable. The posterior segment examination revealed moderate anterior vitreous cells. The retina showed cotton wool spots in the macular area and surrounding the optic disc (Fig 1). The retinal arteriole of both the superior and inferior arcade appeared to be occluded, with presence of blot retinal haemorrhages at the superotemporal retina. The macula was swollen, but the optic disc appeared normal. Examination of the right eye was normal. Systemic examinations did not reveal any signs of cardiovascular, pulmonary, or renal abnormalities.

The optical coherence tomography (OCT) of the left macula showed presence of intraretinal and subretinal fluid (Fig. 2). Fundus fluorescein angiography (FFA) of the left eye showed vasculitic changes, with leakage of superior and inferior macular vessels and capillary nonperfusion in the inferior macula and temporal retina (Fig. 3).

Blood autoimmune screening showed raised perinuclear staining ANCA (P-ANCA) levels of 1:20. Other autoimmune screenings including diffuse cytoplasmic ANCA 
(C-ANCA), extractable nuclear antigen (ENA) antibodies, antinuclear antibody (ANA), and antidouble stranded-deoxyribonucleic acid (ds-DNA), complement (C) factor C3 and C4, lupus anticoagulant, and anticardiolipin antibody were all normal. Her full blood count showed eosinophilia, as the differential count for eosinophils from the full blood count was $5.5 \times 10^{8} / \mathrm{L}$. This was confirmed by peripheral blood film, which also showed eosinophilia. Other blood investigations for renal profile, liver function test, erythrocyte sedimentation rate (ESR), and C-reactive protein (CRP) were all normal. Additionally, the Mantoux test was negative, with normal chest radiography findings. Blood tests for Treponema pallidum haemagglutination (TPHA), as well as serology for toxoplasmosis and herpes were also negative. As P-ANCA and eosinophilia were positive, further pulmonary and cardiovascular assessments were performed to rule out the diagnosis of Churg-Strauss syndrome. However, both chest radiography and echocardiography were normal, with no signs of congestive heart failure or pulmonary failure.

The patient was diagnosed to have AAV and she was comanaged together with the rheumatology team. Treatment was initiated with intravenous methylprednisolone $1 \mathrm{gm}$ per day for 3 days, followed by oral prednisolone $1 \mathrm{mg} / \mathrm{kg} /$ day. It was tapered by $5 \mathrm{mg}$ every week for 6 weeks and maintained at $10 \mathrm{mg}$ per day.

At month 3 of follow-up, visual acuity in her left eye remained as counting fingers. The fundus examination showed similar ischemic vasculitic changes. Repeated OCT of the left macula showed complete resolution of intraretinal and subretinal fluid. However, there was loss of hyper-reflectivity of the contour of the macular layers and atrophic changes of the photoreceptor and retinal pigment epithelium layers.

\section{Discussion}

ANCA is an autoantibody with a specific preference for neutrophil granules and monocyte lysosomes. ANCA is strongly related to systemic vasculitis. There are two main recognisable patterns of ANCA based on the staining properties on the neutrophils, namely, C-ANCA and P-ANCA. ${ }^{1}$ C-ANCA is commonly positive in patients with Wegener's granulomatosis (WG), while P-ANCA is more commonly seen in patients with microscopic polyangiitis (MPA) and Churg-Strauss syndrome (CSS). ${ }^{2}$

The incidence of WG is the highest among the three syndromes and constitutes half of the disease population. ${ }^{3}$ The incidence of WG is higher in northern Europe compared to MPA, which is more commonly seen in southern Europe and Japan. In terms of ethnicity, the disease occurs predominantly among Caucasians. Despite a known presentation onset in the range of 65-74 years of age, it can, however, occur at any age. Although there is higher prevalence among men, women tend to be diagnosed at a younger age. ${ }^{4}$ To date, no studies on the prevalence of AAV in Southeast Asia have been published.

AAV is a multisystemic disease with various systemic presentations. From the 


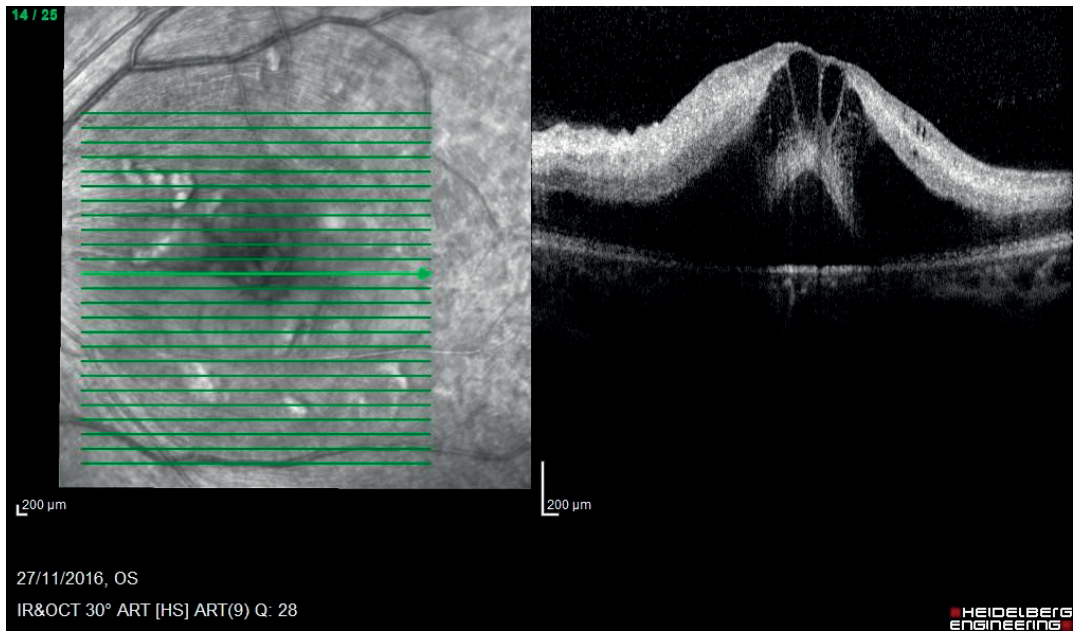

Fig. 2. Left eye OCT showed presence of intraretinal and subretinal fluid.

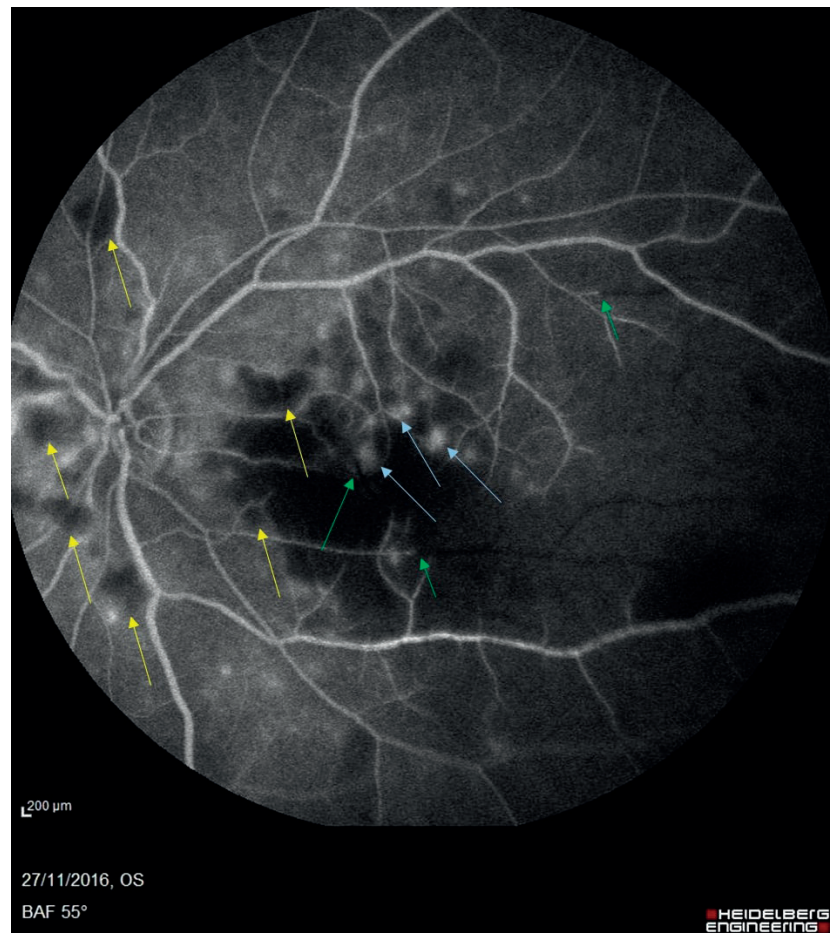

Fig. 3. Left eye FFA at late phase showed interrupted blood flow in arterioles (green arrows), masking effect of the rounded cotton wool spots (yellow arrows), and fluid leakage from the capillaries due to vasculitis (blue arrows). 
cases reported, the commonest systemic disease is renal disease, followed by malaise and general weakness; pulmonary haemorrhages; skin rashes and ear, nose and throat-related diseases as well as sinusitis. ${ }^{5,6}$ Ocular involvement is highly uncommon in AAV. ${ }^{5,6}$ However, the findings could vary between WG, MPA, and CSS.

In the case of MPA, patients can have rapidly progressive renal failure due to severe glomerulonephritis. In addition, patients can also present with dyspnoea and haemoptysis with lung involvement. The commonest ocular presentation in MPA is peripheral ulcerative keratitis, which could lead to corneal perforation. Conjunctival and lid nodules with central ulceration can be seen as well. In addition, patients can have recurrent severe necrotising scleritis and episcleritis, leading to chronic choroidal inflammation. The chronic choroidal inflammation can in turn lead to extensive exudative retinal detachment, thus causing vision loss. There were reported cases of central retinal artery occlusion. However, presentations of retinal vasculitis are rare. ${ }^{6}$

For WG, the classical triad for clinical diagnosis is focal segmental glomerulonephritis, respiratory tract vasculitis, and necrotising vasculitis of the small arteries and veins. ${ }^{6}$ Nearly half of the patients will have orbital and ocular inflammation. The presenting signs and symptoms include restrictive extraocular muscle movement, consequently causing diplopia, proptosis due to inflamed orbital content - which in turn can lead to exposure keratopathy -, and compressive optic neuropathy, occlusive retinal vasculitis, choroiditis, scleritis, episcleritis, and ischemic optic neuritis. ${ }^{6}$

Eosinophilic granulomatosis with polyangiitis or CSS is an allergic granulomatous angiitis. Clinically, the patient can have systemic cardiac involvement and present with congestive heart failure and restrictive cardiomyopathy. In terms of ocular involvement, patients can have granuloma nodules over the lid, conjunctivitis, episcleritis, marginal ulcerative keratitis, branch retinal vein occlusion, optic disc vasculitis, retinal infraction, and ischemic optic neuropathy. Moreover, patients can also present with cranial nerve palsy and ocular myositis, which could affect ocular motility. ${ }^{6}$ The ocular and systemic presentations of AAV are summarized in Table 1.

\section{Conclusion}

AAV is a rare vasculitic disease, especially in Southeast Asian countries. It can occur in young patients, even though the age of onset is usually 64-75 years old. Patients presenting with clinical features similar to the ones outlined in this case report should be investigated with a high grade of suspicion for AAV. Serology ANCA can help to diagnose the disease. Following diagnosis, patients diagnosed with AAV should be managed with multidisciplinary follow-ups. 
Table 1. Clinical features and investigations for ANCA associated vasculitis ${ }^{7}$

\begin{tabular}{|c|c|c|c|}
\hline & $\begin{array}{l}\text { Microscopic } \\
\text { polyangiitis (MPA) }\end{array}$ & $\begin{array}{l}\text { Wegener's } \\
\text { granulomatosis (WG) }\end{array}$ & $\begin{array}{l}\text { Churg-Strauss } \\
\text { syndrome (CSS) }\end{array}$ \\
\hline \multicolumn{4}{|l|}{$\begin{array}{l}\text { Systemic } \\
\text { involvement }\end{array}$} \\
\hline Renal & + & + & \\
\hline Pulmonary & + & + & \\
\hline Cardiovascular & & & + \\
\hline \multicolumn{4}{|l|}{$\begin{array}{l}\text { Ocular } \\
\text { involvement }\end{array}$} \\
\hline Orbital mass & & + & \\
\hline Myositis & & + & + \\
\hline Conjunctivitis & + & + & + \\
\hline Scleritis & & + & \\
\hline Episcleritis & & + & + \\
\hline $\begin{array}{l}\text { Peripheral } \\
\text { ulcerative keratitis }\end{array}$ & + & + & + \\
\hline Retinal vasculitis & + & + & + \\
\hline $\begin{array}{l}\text { Neuro-ophthalmic } \\
\text { involvement }\end{array}$ & & + & + \\
\hline \multicolumn{4}{|l|}{$\begin{array}{l}\text { Specific } \\
\text { investigation }\end{array}$} \\
\hline P-ANCA & + & & + \\
\hline C-ANCA & & + & \\
\hline Eosinophilia & & & + \\
\hline Chest radiography & & + & + \\
\hline Echocardiography & & & + \\
\hline
\end{tabular}

\section{Acknowledgements}

The authors report no conflicts of interest and are solely responsible for the content and writing of the paper. Informed consent was obtained from the patient for publication of this case report and any accompanying images. 


\section{References}

1. Tsiveriotis K, Tsirogianni A, Pipi E, Soufleros K, Papasteriades C. Antineutrophil cytoplasmic antibodies testing in a large cohort of unselected Greek patients. Autoimmune Diseases. 2011;2011(1):1-9. doi:10.4061/2011/626495.

2. Kamesh L, Harper L, Savage CO. ANCA-positive vasculitis. J Am Soc Nephrol. 2002;13(1):1953-1960.

3. W Koldingsnes, HC Nossent. Epidemiology of ANCA associated vasculitis. Norsk Epidemiologi. 2008;18(1):37-48.

4. Berden A, Göçeroglu A, Jayne D, et al. Diagnosis and management of ANCA associated vasculitis. BMJ. 2012;334(e26):1-10. doi: 10.1136/bmj.e26.

5. Levy JB, Hammad T, Coulthart A, Dougan T, Pusey CD. Clinical features and outcome of patients with both ANCA and anti-GBM antibodies. Kidney Int. 2004;66:1535-1540.

6. Gallagher MJ, Ooi KG, Thomas M, Gavin M. ANCA associated pauci-immune retinal vasculitis, $\mathrm{Br} J$ Ophthalmol. 2005;89:608-611. doi:10.1136/bjo.2004.051177.

7. Shorya VA, Brijesh T, Pradeep V. Eye and Vasculitis. J Vasc. 2016;2(2):1-10. doi:10.4172/24719544.100108 . 